\title{
Urbanisation in a formal way? The different characteristics of the 'newest towns' in Poland and Hungary
}

Barbara KoneckaSzydłowska Institute of Socio-Economic Geography and Spatial Management

Adam Mickiewicz University,

Poland

E-mail: bako@amu.edu.pl

András Trócsányi

(corresponding author)

Institute of Geography and Earth

Sciences

University of Pécs,

Hungary

E-mail: troand@gamma.ttk.pte.hu

Gábor Pirisi

Institute of Geography and Earth

Sciences

University of Pécs,

Hungary

E-mail: pirisig@gamma.ttk.pte.hu
The recent urbanisation of Poland and Hungary can be characterised by two main processes, urban sprawl, suburbanisation on the one hand, birth of new towns from villages through a legal process on the other hand, that have provided significant changes in the share of urban population. Suburbanisation has been investigated in details throughout the post-socialist region, while formal urbanisation could gain less attention, although in certain cases like in Hungary it has doubled the number of towns and cities within less than three decades. The present study introduces the similarities and differences of the formal urbanisation process in Poland and Hungary, giving an evaluation of the new-born towns. Their size and socioeconomic development are measured and contrasted on the basis of statistical indices, furthermore, their geographic location and functions in the settlement network are compared, too.

Keywords:

formal urbanisation, town rank, post-socialist urbanisation, Polish-Hungarian comparison, socio-economic development 


\section{Introduction}

In many countries of Europe, the difference between towns and villages is not only a question of history, functions, size, demography or morphological character, but also a matter of legal and administrative status. The legal system of both Poland and Hungary distinguishes different types of municipalities, and allows the evolvement from the lower to the higher level through a specific legal procedure. As it has been a popular and desired milestone among developed villages, the number of towns has increased significantly in the past almost three decades. The process is also manifested in the growth of the overall urbanisation rate; however, the pace of functional (classical) urbanisation in fact is rather limited. In other words: recent urbanisation has been decisively characterised by formal urbanisation. If urbanisation is mostly a legal procedure of reclassification, researchers are more and more interested in the professional background of the legislation and also in the discrepancies and conflicts between theory and everyday practices.

The aim of the present paper is to compare the post-socialist formal urbanisation in Poland and in Hungary. With the cooperation of researchers in both countries, it tries to answer the following questions:

- What have been the main characteristics of the formal urbanisation process (conferring municipal rights/gaining town rank) in Poland and Hungary since 1989 ?

- What are the similarities and differences in the sets of new towns in Poland and Hungary?

- What is the level of socio-economic development of new towns in Poland and in Hungary?

\section{Formal urbanisation, settlement reclassification, and new towns: some hints about the terms and concepts}

The term of formal urbanisation is barely used in literature anywhere else but in Hungary. The concept refers to the difference between the most common way of urbanisation (the growing population of towns and cities via natural increase and more often immigration) and the process, when the number of urban population is increasing as the result of via statistical-legislative transformation. The process is either based on both statistical automatism (for example reaching a specified population limit) and individual (political) decisions - the legal background and practice of the latter highly varies throughout Europe (Kocsis 2008). The term of 'urban reclassification' is used more often (Kulcsár-Brown 2011), but it hides the fact that the phenomenon is more than a statistical act. Reclassification today may appear as a difficulty for researchers trying to evaluate urbanisation process in rapidly developing and urbanising countries of Asia and Africa (Goldstein 1990, Obeng-Odoom

Regional Statistics, Vol. 8. No. 2. 2018: 135-153; DOI: 10.15196/RS080202 
2010, Pradhan 2013). However, the question has been frequently appeared in connection of socialist and post-socialist urbanisation (Bujdosó-Kovács 2016, Mladenov et al. 2010, Pirisi-Trócsányi 2009a, Konecka-Szydłowska 2017, KoneckaSzydłowska 2011, Krzysztofik-Dymitrow 2015, Sokołowski 2014, SzymańskaMatczak 2002). During the decades of planned economy, reclassification used to be an effective tool for the centrally forced and administered development of urban network (Kocsis-Lenner 2012), in many cases on pure political-ideological basis (preference of industrial towns). Reclassification somehow reflects the desired modernisation of the society - cities and towns; even the small ones were outpost of modernity in a dominantly rural environment. It was among the aims of (even formal) urbanisation to establish modern infrastructure and institutions to provide higher living standards. However, during the years of socialism the (party-led) state initiated and controlled the overall upside-down process.

After the political transition and during the long, and in many aspects still unclosed economic and social transformation, conditions of urbanisation changed fundamentally. Although the transformation of intra-urban spaces and big cities themselves have become the most important issues of settlement/urban geography, many papers underline the importance of suburbanisation (Andrusz et al. 2008, Hirt 2012, Sailer-Fliege 1999, Stanilov 2007, Szabó-Szabó-Kovács 2014, Timár-Váradi 2001, Tsenkova 2006, Kajdanek 2012), the exhaustion of the sources of urbanisation, the end of urban expansion (Brown-Schafft 2002, Enyedi 1998, Kovács 2004), and even the occurring of shrinking in urban Central Europe (Haase et al. 2013, Stryjakiewicz 2014). Papers regarding the topic of lower-level urbanisation in Central-Europe need to take into consideration that these processes are deeply rooted in some major phenomena of the region: ageing (Kulcsár-Brown 2017), polarisation and marginalisation taking place in rural areas (Nagy et al. 2016).

The conditions of urbanisation with slow natural increase or even relatively intensive decrease of population, the growing percentage of international emigration after the year of 2004, the quick expansion of suburban lifestyle, the collapse of many former industrial centres came to an end of urbanisation in its traditional meaning in several countries of the former Soviet Bloc (Kovács 2010). The population of cities and towns has hardly increased during the last two decades, however, villages - mostly with suburban location - gained population surplus. Under these circumstances, exacerbated with a constant demographic decline, formal urbanisation or reclassification in Hungary became the sole way of urban population growth.

As the number of towns has doubled since 1990 in Hungary, the process is quite spectacular; therefore, urban classification is a matter of widespread discussion not only among geographers (Bujdosó et al. 2014; Pirisi-Trócsányi 2009b, 2012; Szabó 2015; Szigeti 2002; Tóth 2008). Beyond the 'moral' evaluation of the process (whether it is 'good' or 'harmful' for the urban network), questions were raised about the urbanity and about the spatial roles of 'new towns'. Also in Poland since

Regional Statistics, Vol. 8. No. 2. 2018: 135-153; DOI: 10.15196/RS080202 
the start of the socio-economic transformation, the set of Polish towns has kept growing almost from year to year, therefore the issue is widely discussed in the literature (Sokołowski 2014, Zaniewska 2013, Konecka-Szydłowska 2011, SzmytkieKrzysztofik 2011, Drobek 2002, Szymańska 1996).

This normative approach may deflect attention from some more important questions. The local point of view is not about the fitting into the urban network, but about the utilisation of a possible (small) competitive advantage that a town rank can give. From this approach, reclassification is a locally driven, bottom-up initiative, where the goal is to strengthen local autonomy. This way it could be interpreted as a pursuit for the increase of local resilience (Robinson-Carson 2016).

These newest towns however, are not to be confused with the most common usage of this term, the newly, 'artificially' planned, designed and located settlements, which are so typical for the $20^{\text {th }}$ century urbanisation both in Western and Eastern Europe (Alonso 1970, Osborn-Whittick 1963). The novelty of these settlements roots only in their administrative status, i. e. their town rank, however, there are some settlements throughout the region, which actually are products of former central planning (smaller industrial sites), or just objects of rapid growth during the last decades (suburban places, holiday resorts). Nevertheless, in many cases, 'new towns' are indeed old ones: traditional central places in rural areas, reaching recently the present threshold of modernity and urbanity manifested in the town status. In several instances (in Hungary particularly less than in Poland, but also in the Czech Republic) town ranks were not awarded to settlements for the first time: they just have regained it after decades of 'exile' from the urban community (Kocsis 2008, Krzysztofik-Dymitrow 2015).

\section{Methodological issues}

This paper combines both qualitative and quantitative methods. The main goal was the parallel evaluation of the reclassification process, which was based on the thorough analysis of legal documents and governmental decisions. The Hungarian authors have spent almost two decades with the participant observation and even as actors of the reclassification as they assisted dozens of municipalities with their application documents through their consultancy work. The timeframe of the research covers the era of the post-socialist development, with a starting year of 1989 in Poland and 1990 in Hungary. All of the researched settlements have reached the desired town rank within this period.

The comparison of new towns is partially based on simple statistical analysis in the first line. Secondly, authors tried to adopt an index-based statistical method to highlight the differences between Polish and Hungarian new small towns. Indices of socio-economic phenomena are necessary to apply to make a correct assessment of processes taking place in the social and economic spheres (Czyż 2016). In the meth-

Regional Statistics, Vol. 8. No. 2. 2018: 135-153; DOI: 10.15196/RS080202 
odological sense, an index is a feature, occurrence or phenomenon on the basis of which we conclude with certainty (or with a specified degree of probability) that the phenomenon of interest to us is actually present (Nowak 2007). The basic classification indices employed in this study are as follows:

- structural indices which present the ratio of the number of units with the given value of a variable to the size of the sample; structural indices are expressed in per cent, e.g. the proportion of urban population;

- intensity indices which present the number of cases of the phenomenon examined in relation to the total number of units in the statistical population from which the phenomenon derives, e.g. the total number of enterprises per 1,000 inhabitants; and

- growth indices which define the relation between figures characterising some quantity (phenomenon) in two periods or moments of time and are expressed in per cent, e.g. total urban population growth in percent against a reference year (1990-2013).

To evaluate the position of the new towns in Poland and Hungary on the scale of socio-economic development, eight indices were used for four aspects: population, economy, housing infrastructure, and social capital.

Table 1

List of socio-economic indices examined

\begin{tabular}{|c|c|}
\hline Aspect & Index \\
\hline Population & $\begin{array}{l}x_{1}-\text { Population density in } \mathrm{km}^{2} \\
x_{2}-\text { Natural increase in } \% 0 \\
x_{3}-\text { Net migration in } \% 0\end{array}$ \\
\hline Economy & $\begin{array}{l}x_{4}-\text { Economic dependency ratio - number of persons of non-working age } \\
\text { per } 100 \text { persons of working age (destimulant variable) } \\
x_{5}-\text { Number of employees per } 1,000 \text { inhabitants } \\
x_{6} \text { - Number of enterprises per } 1,000 \text { inhabitants }\end{array}$ \\
\hline $\begin{array}{l}\text { Housing infra- } \\
\text { structure }\end{array}$ & $x_{7}-$ Usable floor space in $\mathrm{m}^{2}$ per 1 inhabitant \\
\hline Social capital & $x_{8}-$ Number of NGOs per 1,000 inhabitants \\
\hline
\end{tabular}

Regional Statistics, Vol. 8. No. 2. 2018: 135-153; DOI: 10.15196/RS080202 


\section{Mathematical-statistical methods}

To obtain a linear arrangement of the new towns in terms of their socio-economic development level, Perkal's synthetic index (z-score index, see Perkal 1953, Kostrubiec 1965, Smith 1972, Runge 2006) was used in the following form:

$$
W_{s}=\frac{\sum_{j=1}^{p} z_{i j}}{p},
$$

where $W_{s}$ denotes the synthetic index, $p$ is the total number of variables considered, $j$ is the number of a variable $(1,2, \ldots, p)$, and $z_{i j}$ stands for the standardised value of the $j$-th variable for the $i$-th object.

To use the synthetic index, it was necessary to start with standardising the values of indices describing the intensities of individual variables in towns. For variables of a stimulant nature, standardisation was performed on the basis of the following formula:

$$
z_{i j}=\frac{x_{i j}-\bar{x}}{S_{j}},
$$

where $z_{i j}$ is the standardised value of the $j$-th variable for the $i$-th object, $x_{i j}$ is value of the $j$-th variable for the $i$-th object, $\bar{x}$ stands for the arithmetic mean of the values of the $j$-th variable, and $S_{j}$ denotes standard deviation of the values of the $j$-th variable.

For the destimulant type of variables, standardisation followed the formula:

$$
z_{i j}=\frac{\bar{x}-x_{i j}}{S_{j}} .
$$

The standardisation of indices resulted a matrix of standardised features, which were then used to calculate the synthetic indices $\left(W_{s}\right)$. Based on the distribution of the synthetic z-score values $\left(W_{s}\right)$, a linear rank of the new towns in Poland and Hungary was constructed, and their classification was carried out. This led to the separation of classes representing the same level of an indicator. In dividing the new towns into relatively homogeneous classes, the standard deviation values of the population were used. The classification allowed the delimitation of three classes in the total set of towns as high, average and low level of socio-economic development in terms of the indices analysed.

To examine the dependence between the size of the new towns in Poland and Hungary and their levels of socio-economic development (based on the synthetic index $W_{s}$ ), Pearson's coefficient of linear correlation was used.

Regional Statistics, Vol. 8. No. 2. 2018: 135-153; DOI: 10.15196/RS080202 


\section{Similarities and differences in the process of both countries}

First, we need to underline, that there is no dominant approach related to this question among the European states and their practices. Even the comparison itself is hard, because of the quite different structures of local administrative levels. Most of the European countries experienced a significant territorial administrative reform during the 1970-1980s, which resulted in many cases the reduction of communes in their number, building up larger units of local municipalities. In these reforms, legal differences between villages and towns were usually dissolved, which does not mean, that the distinctions in language, even in formal language have disappeared (Kocsis 2008). Only a few data and papers are available in this topic, therefore, we do not set up models, but we are to define some important motives, which appear in several cases.

- Town-village distinction sometimes has become so meaningless that it is presently an issue of only statistical labelling (see for example Sweden, Switzerland) or, in the case of towns (but not of cities!) it is only based on self-definition.

- Despite all rationalisation efforts of European states, still the historical-legal heritage and traditions highly influence the current reclassification practices. The rank of a 'city' is granted by the crown in the United Kingdom, the Czech regulation gives 'automatism' for settlements reclaiming towns rank lost in 1954, and the list can be continued in details with several other European examples (Kocsis 2008).

- In the less-urbanised Eastern edge of Europe, the reclassification is often used as a tool (or replacement) of regional development (initiatives and resources): settlements gain town rank might generate more dynamism in spatial progresses - this is the main factor in Romania (Veress 2016), but also not unknown in Hungary. In addition, political influence on the process become more and more visible when moving eastwards (Berekméri 2006).

How do Hungary and Poland fit into this colourful European picture of urban reclassification? In the first place, we can underline that with different importance, but both the 'historical' and the 'regional political' approaches have influence on these countries' practices.

While descriptions in native language have been long available about the legal regulation of the reclassification process, there are hardly any papers written in English. Therefore, we find it useful, to describe it shortly.

The application, evaluation and selection procedures implemented in these two countries are very similar. In both cases, the 'story' starts (can only start) with a local initiative. It does not necessary mean that it is done by the citizens: most likely, the local political elite, first of all mayors are the key role players. Public consultations in

Regional Statistics, Vol. 8. No. 2. 2018: 135-153; DOI: 10.15196/RS080202 
Poland are obligatory, in Hungary, they are only recommended, but sometimes it is an issue of the local elections' campaign, when candidates give emphasis to the urbanisation as an important local goal. In other cases, not the mayor, but another 'strong man/woman' of local community or even an NGO is the main promoter of the idea.

Anyway, whether it is one source or another, the initiative usually can gain the support of the majority of citizens and decision makers. This majority does not mean uniformity (there are always opponents), and despite the short-term political goals the argumentation is very similar: people have fears to lose values connected to rural traditions - as they usually think that formal urbanisation will implement decisive transformation in their everyday life, a kind of intensive functional urbanisation. Ironically, sometimes communities in the agglomerations and residents moved out from the capitals have the biggest disapproval. At least in one documented case, in Solymár (that is located northwest from Budapest, Hungary, and its actual population is slightly over 10,000) the resistance of some influencing groups and stakeholders (who may own even a majority among the voters) was able to abort the planned initiation. Further Hungarian speciality is that professional consultants play a key role not even in the creation of the proposal, but in the diffusion of the innovation of formal urbanisation by draw communities' attention to the possibilities and encourage local stakeholders. Without them, the number of new towns in Hungary should be significantly less.

After the initiative is formed at local level, the support of higher political and administrative levels must be gained. In Poland, both powiat (district, LAU 1) and voivodeship (province or region, NUTS 2) need to support the proposal. A formal support is not necessary in Hungary from the megye (county, NUTS 3, the only higher administrative level with an elected body), but usually aspirants try to get the county's official and informal political support.

Proposals are to be addressed to the relevant ministers - during the last decades, there were many transformations in governments' structure, the name and responsibility of ministries were anything but permanent. Nowadays, in Poland the Ministry of Interior and Administration, in Hungary the Minister of Prime Minister's Office governs the process. They are both authorised to make decision, but in Hungary, an advisory board is also involved with various members of politics, science, public administration and associations of local municipalities.

The evaluation process contains in both countries a sort of 'soft' or subjective elements leaving a wide-open space for political deliberation. In Poland, the criteria used are a bit more concrete compared to the Hungarian practice, however, the latter one was significantly modified in 2015 closing the gate for the growing number of applicants. The Polish evaluation tries to be comprehensive with four factors: 1. demography, including a minimum population of 2,$000 ; 2$. engineering and 3. morphology, demanding an urban layout and developed infrastructure, and

Regional Statistics, Vol. 8. No. 2. 2018: 135-153; DOI: 10.15196/RS080202 
4. central functions, including the predominance of the non-agricultural employment. The possession of the past town rank could also be an advantage during the evaluation (Sokołowski 2014).

In Hungary, the main theoretical criteria are 1. development level (exceeding the average of small towns) and 2. central functions. Traditionally, a long list of statistical measures was published to be used for the evaluation, but without defining any threshold to be reached for each criteria (Pirisi-Trócsányi 2009). After the latest (or last) massive pool of applicants and successful candidates (in 2009 22, in 2013 18 new towns), a significant restriction was introduced in 2015. A new list of indices was developed, and target values were also added to each criterion. For example, as a main spatial criterion, a ratio of minimum $20 \%$ of incoming commuters within the locally employed is required, which is can be fulfilled by majority of the potential new candidates, however, the important local labour centres are already possessing town rank (Pénzes et al. 2015). A constantly growing population and the limit of 10,000 (!) inhabitants were also published, but textually they are rather expectations than requisites (meanwhile the country has an annual population loss of $-0.25 \%$, and there are 202 towns with population less than 10,000). Although the new regulation theoretically gives the possibility for a flexible evaluation, the recent practice has become quite rigorous without any settlement reclassified since then. Therefore, reclassification was and remained primarily a political decision.

\section{Effects of reclassification on the urban network}

While the procedure is or was very similar in Poland and Hungary, the scale, effects and partly the goals are different. There are important discrepancies between the two countries' urban structure: a highly monocentric Hungary on the one hand, and a polycentric Poland on the other. Polycentricism of Poland is reflected in the higher number of cities over 200,000 people and in the higher ratio of people in these cities (see Figure 1). Despite of this, the smallest towns (with population under $20,000)$ give not only a larger proportion in Hungary $(81 \%$ compared to $75 \%$ in Poland), but also provide home for $32.0 \%$ of the urban population $(21.4 \%$ in Poland). Thus, somewhat simplified, this is the sign of a lower concentration in urban network - if we do not consider the capital cities.

Regional Statistics, Vol. 8. No. 2. 2018: 135-153; DOI: 10.15196/RS080202 


\section{Structure of urban settlements and urban population, 2016}

Figure 1
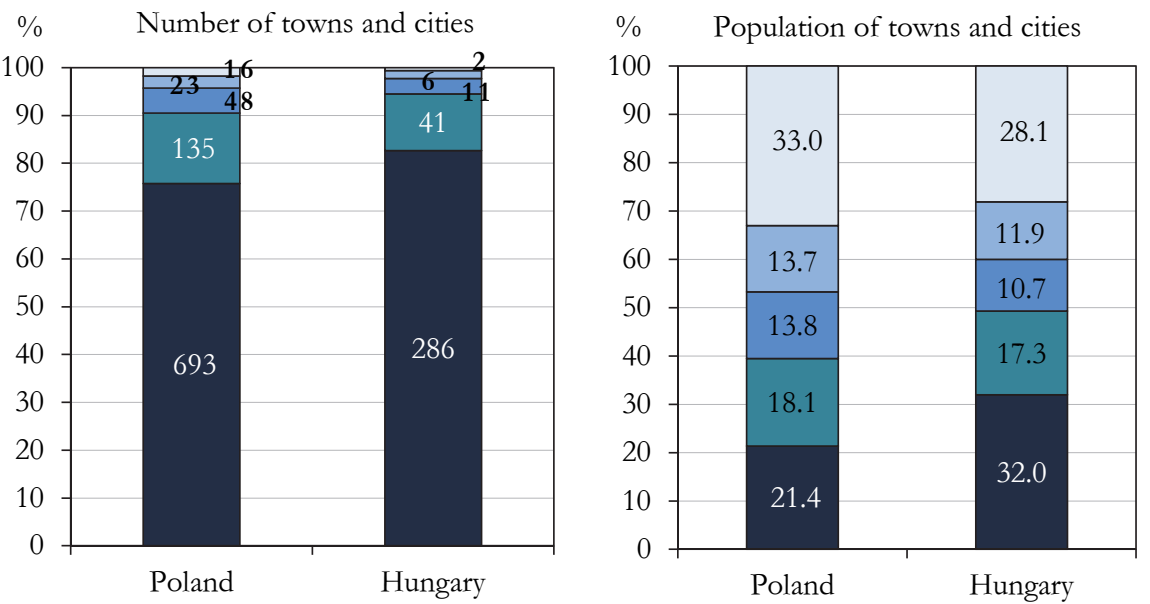

口Under 20,000 $\square 20,000-49,999 \square$ 50,000-99,999

$\square$ 100,000-200,000 $\square$ Over 200,000

Source: Gábor Pirisi's calculation based on 2011 Census data of Poland and Hungary.

Figure 2

The increasing number of cities and towns in Poland and Hungary

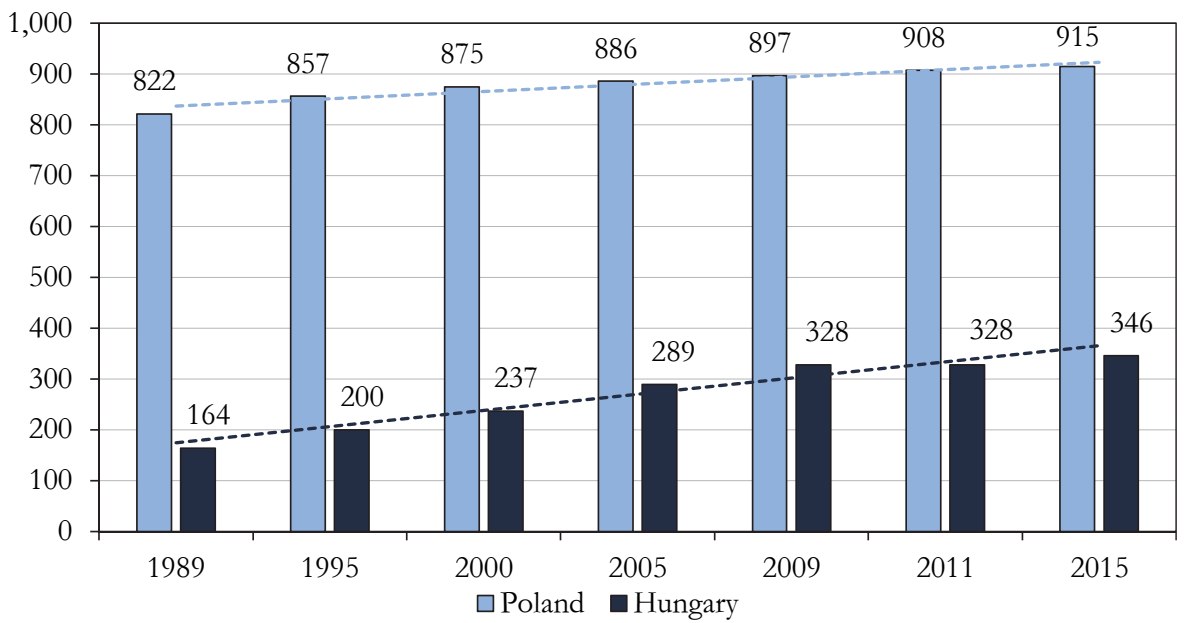

The reclassification process itself was much more intensive and transformed more detectable the structures in Hungary than in Poland. By adding 93 new towns to the network in the latter case, the total number of urban ranked places has grown with $11 \%$. Meanwhile in Hungary, 182 new towns resulted more than the doubling of the starting number. Finally, the 915 Polish cities and towns mean slightly more 
than $60.0 \%$ rate of urbanisation, and the 346 Hungarian urban unit ends up in $70.5 \%$. It seems that Hungary has become a bit 'over-urbanised' from a formal point of view - which is actually the explicit or somewhat hidden opinion of many authors of published papers in this topic throughout the recent years (Bujdosó et al. 2014, Csapó-Kocsis 2008, Németh 2009).

The label 'over-urbanised' for Hungary may go too far in simplification or in criticism. If we look at the population of new towns, there is a clear difference between the two countries: the majority of new towns in Poland ${ }^{1}$ have inhabitants between 2,000 and 5,000. There are only 15 Polish new towns over 5,000 citizens, while 95 Hungarian new towns belong to this populous category (see Figure 3). The latter number could be interpreted also as underlining the (previous) 'underurbanisation' of Hungary compared to Poland, where the formal urbanisation has only reserves in this lower population class.

\section{Population categories of new towns in Poland and Hungary, 2016}

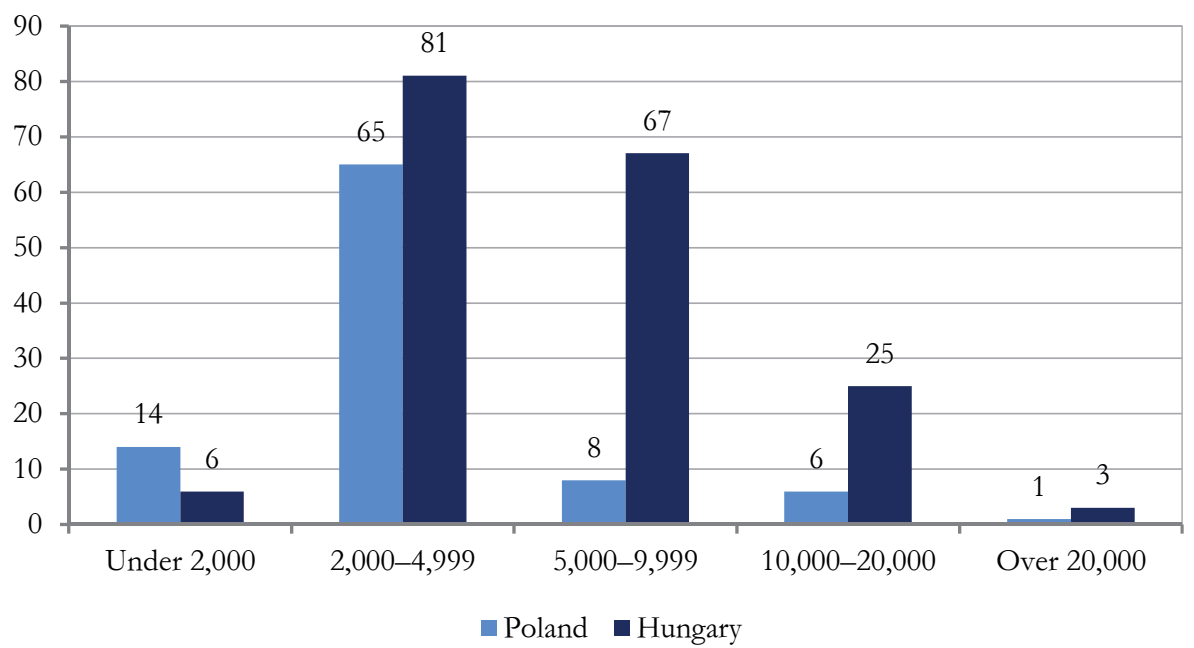

Source: Gábor Pirisi's calculation based on 2011 Census data of Poland and Hungary.

These differences can be explained by the dominant (functional) types of new towns. In Poland, a kind of 'historical restitution' is among the major motivations behind the process. Town rank very often (in $71 \%$ of all cases) was given to settlements that had historically owned former privileges. In most of the cases, these are smaller and less dynamic places. Towns with significant urban historical heritage

${ }^{1}$ From an economic point of view, for municipalities with more than 5,000 inhabitants, obtaining the town rank is disadvantageous as they are to receive limited amount of educational subsidy and lose preferential conditions for co-financing investments from EU funds (Konecka-Szydłowska-Perdał 2017).

Regional Statistics, Vol. 8. No. 2. 2018: 135-153; DOI: 10.15196/RS080202 
also exist in Hungary among the reclassified settlements, but in these instances, the rank was lost the latest during the late $19^{\text {th }}$ century, in some cases much earlier. Several of these towns still keep traditional urbanity in character (at least some monuments, heritage elements - see Zsámbék, Csákvár, Lébény, Pécsvárad in Hungary, and Frampol, Tykocin, Nowy Wiśnicz in Poland), but their traditions are often bound to market towns - a 'semi-urban' category, especially in their physical appearance. However, historical values and heritage were arguments in the application process, but almost never decisive, and the majority of new towns in Hungary had hardly any urban past. Some of them have not even existed 100 years ago. Thus, the typical new town in Hungary is located in the agglomeration of Budapest and has a relative high population (8,000-12,000), a dynamic growth through suburban migration. Nevertheless, the typical Polish new town is more traditional, smaller and usually located in rural areas or at least outside large urban agglomerations.

\section{Population of new towns in Poland and Hungary, 2016}

Figure 4
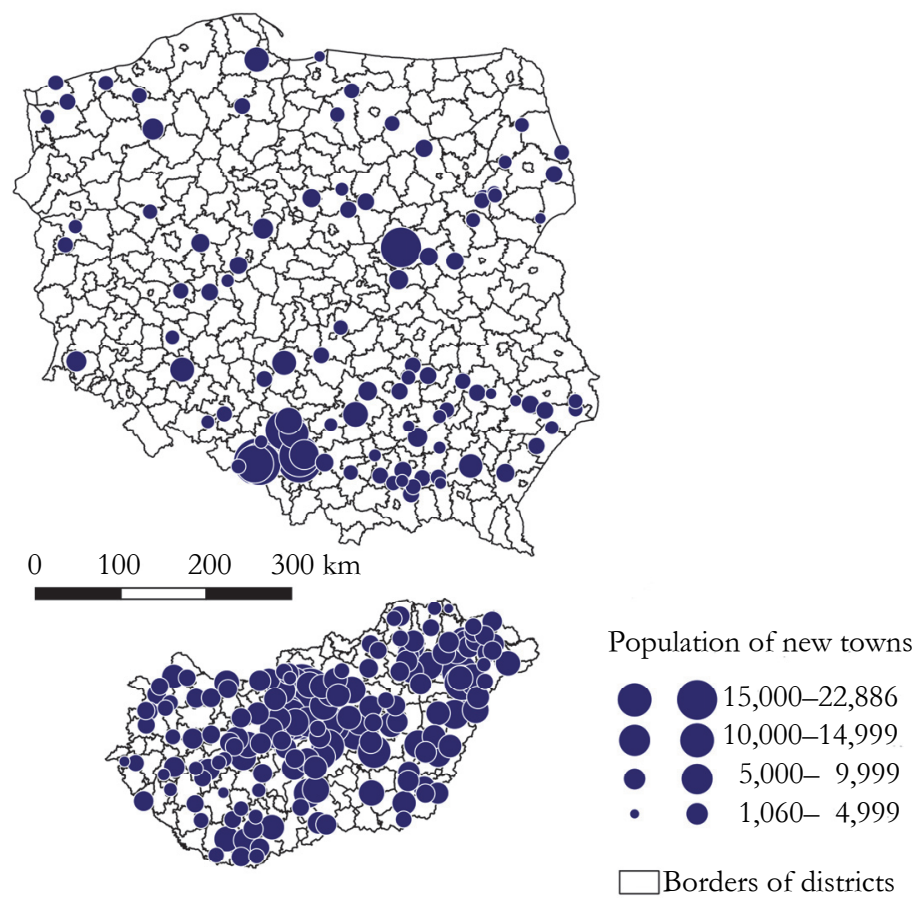

Source: Gábor Pirisi's elaboration based on 2011 Census data of Poland and Hungary.

Finally, by taking a short look on the maps of Figure 4, one can identify the difference in the location of new towns between the two countries. While Hungarian new towns spread - with some concentrations around Budapest and the Eastern

Regional Statistics, Vol. 8. No. 2. 2018: 135-153; DOI: 10.15196/RS080202 
peripheries - almost consistently, in Poland extensive regions can be found. However, some focuses could also be observed in Poland: the relatively large new towns of Upper Silesia (Ledziny, Bierun, Rydułtowy, Radlin), a few around the capital, and a disperse network in the Eastern part of Małopolska.

\section{The index of new towns}

The index-based comparison of Polish and Hungarian towns is informative. Foremost, there are general differences between the two countries in some basic data used for the indices; however, the overall evaluation shows that Polish towns perform better. There are two reasons for this. First, the overall demographic situation is much more favourable in Poland than in Hungary. With a natural decrease of $3.3 \%$ in Hungary and $0.0 \%$ in Poland (Eurostat Demographic Statistics, 2014), the components based on demographic data are definitely higher in Polish towns without any real significance for the small towns' position in the urban network. Looking at economy-based indicators, the picture is more diverse: Polish towns perform better by the number of enterprises, but are weaker at the employment rate. The numbers of NGOs are quite similar, and Hungarian citizens seem to own somewhat bigger houses in Hungary - although this element of the index is the less reliable. ${ }^{2}$ The mean of Polish towns is 0.206 with a standard deviation of 0.39 and a median of 0.130 . In Hungary, the mean $(-0.105)$, the standard deviation (0.28), and the median value $(-0.131)$ are definitely lower.

We also investigated the connection between population size and the index score (see Figure 5). The connection is not strong, but the differences of the two samples can be recognised quite easily. Correlation with the population size is a bit higher in Hungary, however, it is only indirectly caused by the size. The bigger new towns in Hungary are actually not better-developed centres with more spatial functions, but parts of the Budapest agglomeration with intensively growing, well-educated and employed population (see Table 2).

${ }^{2}$ Hungarian regional statistics does not publish data on the average size of flats, but only on the number of flats according to floor-size categories. Therefore, this data was created by an estimation using the number of flats in categories and the arithmetic mean of category values.

Regional Statistics, Vol. 8. No. 2. 2018: 135-153; DOI: 10.15196/RS080202 
Synthetic index of new towns in Poland and Hungary, 2016

Figure 5

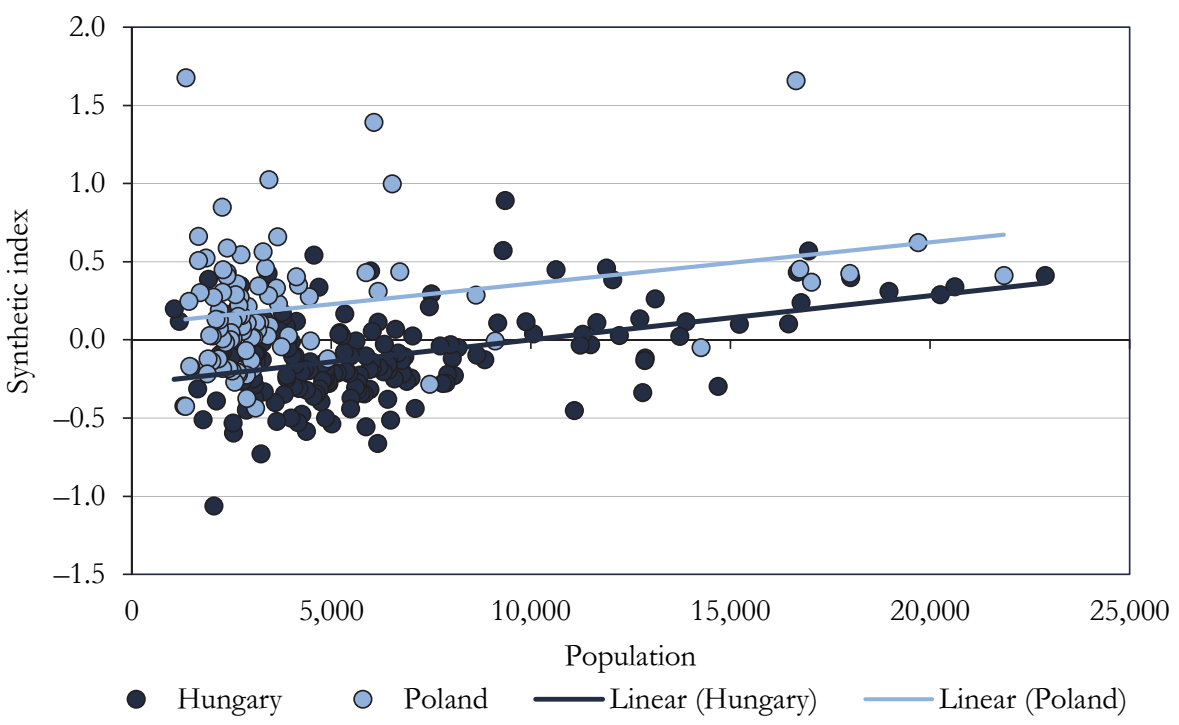

Table 2

The best and the worst performing Polish and Hungarian new towns according to $z$-score values, 2016

\begin{tabular}{l|c|c|l|c|c}
\hline \multicolumn{1}{c|}{ Poland } & \multicolumn{3}{c}{ Hungary } \\
\hline New town & $\begin{array}{c}\text { z-score } \\
(W)\end{array}$ & $\begin{array}{c}\text { Combined } \\
\text { (PL-H) } \\
\text { position }\end{array}$ & New town & $\begin{array}{c}\text { z-score } \\
(W)\end{array}$ & $\begin{array}{c}\text { Combined } \\
(\text { PL-H }) \\
\text { position }\end{array}$ \\
\hline Krynica Morska & 1.68 & 1 & Diósd & 0.89 & 6 \\
Łomianki & 1.66 & 2 & Halásztelek & 0.57 & 12 \\
Siechnice & 1.39 & 3 & Szigethalom & 0.57 & 13 \\
Rzgów & 1.02 & 4 & Rácalmás & 0.54 & 16 \\
Żukowo & 1.00 & 5 & Maglód & 0.46 & 20 \\
Koprzywnica &.- .27 & 219 & Tompa & -0.59 & 269 \\
Miasteczko Śląskie & -0.28 & 224 & Rudabánya & -0.60 & 270 \\
Ryglice & -0.37 & 245 & Újszász & -0.66 & 271 \\
Kleszczele & -0.43 & 252 & Borsodnádasd & -0.73 & 272 \\
Kunów & -0.44 & 253 & Gyönk & -1.06 & 273
\end{tabular}

Regional Statistics, Vol. 8. No. 2. 2018: 135-153; DOI: 10.15196/RS080202 
Hungarian towns performing the best in factors of social wellbeing and liveability are not outstanding in this respect (Pirisi 2009). Four among the five highest ranked towns are located not more than $15 \mathrm{~km}$ away from the administrative border of Budapest. The fifth one, Rácalmás is a suburb of the former socialist city (a new town of 1951), Dunaújváros, and a location of one of the biggest green field investments of the last decade (a plant of Hankook tyres). In Poland, many of the best performing towns are also parts of various agglomerations; according to the polycentric structure of urban network, it does not mean Warsaw (Lomianki) only, but Łódz (Rzgów) and Wrocław (Siechnice) also appear as centres. The first place (including all towns in both countries) is occupied by Krynica Morska, a touristic resort at the seaside - with only 1,300 inhabitants (Konecka-Szydłowska-Perdał 2017, Konecka-Szydłowska 2018). This type of touristic towns also appears in Hungary. The overall economic performance and life quality in these towns (like Bük, Harkány, Zalakaros) are quite high, but the structure of the population (large proportion of elderly people) is unfavourable as far as the synthetic index is concerned. There are two factors that can be marked as important differences between the two countries: while the best performing Hungarian towns are significantly bigger (their average population is slightly over 10,000 contrasted to 6,800), Polish towns seem to have stronger economic functions. Three among the five best performing Hungarian towns are not really more than large residential suburbs without notable economic importance.

Towns with the lowest index values are heterogeneous and indicate many types of small towns: Rudabánya and Borsodnádasd are former industrial sites, abandoned, and 'covered by rust and social hopelessness'. Újszász (railway junction) located at the inner, Tompa (border crossing point) at the outer peripheries: both of them are traffic nodes. Gyönk is a typical small centre in a remote and fragmented rural area, with strong human, but rather weak economic functions. The latter is the most common type among the weakly performing new towns in Hungary: these towns emerge from their rural environment, but are still determined by the backwardness of the region. In Poland, the worst performing towns are not evidently in remote rural areas: Miasteczko Ślaskie is located next to Katowice, Koprzywnica is not far from Tarnobrzeg, on an important traffic axis, and Kunów is near Ostrowiec Świętokrzyski. Only Kleszczele is on the eastern periphery of the country (near the border with Belarus), while Ryglice is also located in a typical rural area.

\section{Conclusions}

Although there are not any significant differences for the everyday life of local residents, the town rank itself is still attractive at least for the local decision makers. Therefore, formal urbanisation has been dynamic since the political transformation, and resulted the doubling of towns in Hungary, and becoming the only source and

Regional Statistics, Vol. 8. No. 2. 2018: 135-153; DOI: 10.15196/RS080202 
way of urbanisation. In Poland, the reclassification remained as an additional process, and was less significant both in number and in its spatial effects. New towns in Poland are smaller, 'more historical' and more concentrated geographically to the less developed eastern and south-eastern regions (which results from the fact that the largest number of former towns can be found in this part of the country). In Hungary, the main spatial effect is the urbanisation of the suburban rings, not only around Budapest, but also around regional centres and dynamic cities. The larger average population size of the newest towns in Hungary is mainly connected to the larger proportion of these demographically dynamic places.

From this approach, the reserves of urbanisation in Hungary are still not exhausted, if we consider the Polish example. While the predominant majority of Polish new towns have a population between 2,000 and 5,000 people, there are 375 villages in Hungary in this category, while only 24 is over 5,000 and only one (Solymár) is above 10,000.

Another important conclusion is, that the Hungarian reclassification process, which is often considered as a unique one, shows important similarities to the Polish reclassification in goals, steps and evaluation - virtually everything - except its scale. As a bottom-up initiative, reclassification does not really serve higher-level spatial political goals, but reflects local needs and (urban) value choice.

\section{Acknowledgement}

Gábor Pirisi’s work was supported by the János Bolyai Research Scholarship of the Hungarian Academy of Sciences.

\section{REFERENCES}

Alonso, W. (1970): What are new towns for? Urban Studies 7 (1): 37-55. https://doi.org/10.1080/00420987020080031

ANDrusz, G.-HARloe, M.-SzELÉNYI, I. (2008): Cities after Socialism: Urban and Regional Change and Conflict in Post-socialist Societies John Wiley \& Sons, Hoboken. https://doi.org/10.1002/9780470712733

BEREKMÉRI, M. (2006): Új városok Maros megyében Erdélyi Társadalom 4 (2): 83-98.

Brown, D. L.-SchaffT, K. A. (2002): Population deconcentration in Hungary during the post-socialist transformation Journal of Rural Studies 18 (3): 233-244. https://doi.org/10.1016/S0743-0167(01)00046-8

Bujdosó, Z.-DÁvID, L.-UAKHITOVA, G. (2014): The urbanisation in Hungary during the last decade Management Research and Practice 6 (1): 21-31.

Bujdosó, Z.-Kovács, T. (2016): "New” Direction of Urban Development from a Central European Perspective Theoretical and Empirical Researches in Urban Management 11 (2): 54-63.

CSAPÓ, T.-KOCsIS, Zs. (2008): A várossá válás reformja Területi Statisztikea 48 (6): 645-650.

Regional Statistics, Vol. 8. No. 2. 2018: 135-153; DOI: 10.15196/RS080202 
CZYŻ, T. (2016): Metoda wskaźnikowa w geografii społeczno-ekonomicznej Rozumój Regionalny i Polityka Regionalna (34): 9-19.

DrobeK, W. (2002): Polskie nowe miasta (1977-2001) In: SŁODCZYK, J. (red.): Przemiany bayy ekonomicznej $i$ struktury funkcjonalnej miast pp. 71-84., Wydawnictwo Uniwersytetu Opolskiego, Opole.

ENyEDI, Gy. (1998): Transformation in Central European postsocialist cities Discussion Papers (21): 5-47.

GoldsteIN, S. (1990): Urbanization in China, 1982-87: Effects of migration and reclassification Population and Development Review 16 (4): 673-701. https://doi.org/10.2307/1972962

HaAse, A.-Grossmann, K.-RInK, D. (2013): Shrinking Cities in Postsocialist Europe - What Can We Learn from Their Analysis for Urban Theory-Making? RC21 Conference: Resourceful Cities. (29-31 August) Berlin.

HIRT, S. (2012): Iron Curtains: Gates, Suburbs and Privatization of Space in the Post-socialist City John Wiley \& Sons, Hoboken.

KAJDANEK, K. (2012): Suburbanizacja po polsku Zakład Wydawniczy Nomos, Kraków.

KOCSIS, ZS. (2008): Várossá válás Európában Területi Statisz̨tika 48 (6): 713-723.

Kocsis, Zs.-LENNER, T. (2012): The national concept for settlement network development of 1971 and some Western European comparisons In: CSAPÓ, T.-BALOGH, A. (eds.) Development of the Settlement Network in the Central European Countries pp. 7590., Springer, Berlin.

KONECKA-SZYDłOWSKA, B. (2011): Małe miasta nowo utworzone w procesie urbanizacji In: BArtosiewicz, B.-Marszat, T. (red.) Przemiany przestrzeni i potencjalu malych miast $w$ wybranych regionach Polski - z perspektywy 20 lat transformacji pp. 9-25., Wydawnictwo Uniwersytetu Lódzkiego, Lódź.

KONECKA-SZYDLOWSKA, B. (2017): Zróżnicowanie poziomu rozwoju społecznogospodarczego nowych miast. Przykład Polski i Węgier Studia Ekonomiczne. Zeszyty Naukowe Uniwersytetu Ekonomicznego W Katowicach, 327: 145-163.

KoneCKA-SzYDŁOwSKA, B. (2018): Najmniejsze miasta w Polsce w ujęciu koncepcji kontinuum miejsko-wiejskiego Rozwój Regionalny $i$ Polityka Regionalna (41): 151-165. https://doi.org/10.14746/rrpr.2018.41.11

KONECKA-SZYDŁOWSKA, B.-PERDAŁ, R. (2017): Rola nowych miast w lokalnym rozwoju społeczno-gospodarczym Wiadomości Statystyczne, Rok LXII 3 (670): 28-48.

Kostrubiec, B. (1965): Klasyfikacja dynamiczna i wielocechowa województw Polski Biuletyn KPZK PAN (35): 28-49.

KOVÁCS, Z. (2004): Socio-economic transition and regional differentiation in Hungary Hungarian Geographical Bullletin 53 (1-2): 33-49.

KOVÁCs, Z. (2010): A szocialista és posztszocialista urbanizáció értelmezése In: BARTA, GY. et al. (eds.) A területi kutatások csomópontjai pp. 141-157., MTA Regionális Kutatások Központja, Pécs.

Krzysztofik, R.-Dymitrow, M. (eds.) (2015): Degraded and Restituted Towns in Poland: Origins, Development, Problems University of Gothenburg, Gothenburg.

KulCSÁR, J. L.-BROWN, D. L. (2011): The political economy of urban reclassification in post-socialist Hungary Regional Studies 45 (4): 479-90. https://doi.org/10.1080/00343400903496378

Regional Statistics, Vol. 8. No. 2. 2018: 135-153; DOI: 10.15196/RS080202 
Kulcsár, J. L.-Brown, D. L. (2017): Population AGEING in Eastern Europe: Toward a coupled micro-macro framework Regional Statistics 7 (1): 115-134. https://doi.org/ 10.15196/RS07107

Mladenov, C.-Illeva, M.-Ilieva, N.-KaZAKOV, B.-HARdi, T.-RAFFAY, Z. (2010): Urbanizáció Bulgáriában Tér és Társadalom 24 (4): 285-300. https://doi.org/10.17649/TET.24.4.1804

NAGY, E.-NAGY, G.-DudÁs, G. (2016): The uneven transformation of consumption spaces and the rise of new marginalities in Hungary Regional Statistics (6) 2: 149-172. https://doi.org/10.15196/RS06208

NÉMETH, S. (2009): Mintha-városból mintavárost! Területi Statiştikea 49 (1): 8-18.

NOWAK, S. (2007): Metodologia badań socjologicznych Wydawnictwo Naukowe PWN, Warsaw.

Obeng-Odoom, F. (2010): 'Abnormal' urbanization in Africa: A dissenting view African Geographical Review 29 (2): 13-40.

Osborn, F.-WhitTick, A. (1963): The New Towns: The Answer to Megapolis McGraw-Hill, New York.

PÉnZES, J.-MolnÁR, E.-PÁLÓCZI, G. (2015): Local labour system after the turn of the millennium in Hungary Regional Statistics 5 (2): 62-81. https://doi.org/10.15196/RS05204

Perkal, J. (1953): O wskaźnikach antropologicznych Przeglad Antropologiczny 19: 209-219.

PIRISI, G. (2009): Differenciálódó kisvárosaink Földrajzi Közlemények 133 (3): 315-325.

PIRISI, G.-TRÓCSÁNYI, A. (2009a): The transformation of villages into towns - A quantitative way of Hungarian urbanisation Geographia - Studia Universitatis Babes-Bolyai 54 (1): 75-82.

PIRISI, G.-TRóCSÁNYI, A. (2009b): Így készül a magyar város Területi Statisztika 49 (2): $137-147$.

PIRISI, G.-TRÓcsánYI, A. (2012): The development of the Hungarian settlement network since 1990 In: BALOGH, A.-Csapó, T. (eds.) Development of the settlement network in the Central European Countries pp. 63-73., Springer Verlag, Berlin.

PradHAN, K. (2013): Unacknowledged urbanisation: New census towns of India Economic \& Political Weekly 48 (36): 43-51.

Robinson, G.-CARSON, D. (2016): Resilient communities: Transitions, pathways and resourcefulness The Geographical Journal 182 (2): 114-122. https://doi.org/ 10.1111 /geoj.12144

RUNGE, J. (2006): Metody badań w geografii społeczno-ekonomicznej Wydawnictwo Uniwersytetu Śląskiego, Katowice.

SAILER-FLIEGE, U. (1999): Characteristics of post-socialist urban transformation in East Central Europe GeoJournal 49 (1): 7-16. https://doi.org/10.1023/ A:1006905405818

SMITH, D. (1972): Geography and social indicators South African Geographical Journal 54 (1): 43-57. https://doi.org/10.1080/03736245.1972.10559497

Sokotowski, D. (2014): New towns in Poland Bulletin of Geography. Socio-Economic Series, 23(1): 149-160. http://dx.doi.org/10.1515/bog-2014-0010

STANILOV, K. (ed.) (2007): The Post-socialist City: Urban Form and Space Transformations in Central and Eastern Europe after Socialism Springer Verlag, Berlin.

Regional Statistics, Vol. 8. No. 2. 2018: 135-153; DOI: 10.15196/RS080202 
STRYJAKIEWICZ, T. (ed.) (2014): Kurçenie sie miast w Europie Środkowo-Wschodniej Bogucki Wydawnictwo Naukowe, Poznań.

SZABÓ, T.-SZABÓ, B.-KovÁcs, Z. (2014): Polycentric urban development in post-socialist context: the case of the Budapest Metropolitan Region Hungarian Geographical Bulletin 63 (3): 287-301. https://doi.org/10.15201/hungeobull.63.3.4

SzABÓ, T. (2015): A várossá nyilvánítás kérdésköre 2015 után - elmúlt negyedszázad kapcsolódó folyamatainak értékelése Új Magyar Közigazgatás 8 (4): 28-36.

SZIGETI, E. (2002): Nagyközség - egy „szerepkörhiányos” közigazgatási településkategória Területi Statisztika 42 (2): 126-143.

SZMYTKIE, R.-KRZYSZTOFIK, R. (2011): Idea miejskości w Polsce In: NAMYŚLAK, B. (red.) Przekształcenia regionalnych struktur funk.jonalno-przestrzennych, Zmiany funkcionalnoprzestrzenne miast i obszarón wiejskich pp. 25-38., Rozprawy Naukowe IGiRR UW, Wrocław.

SZYMAŃSKA, D. (1996): Nowe miasta w systemach osadniczych UMK, Toruń.

SZYMAŃSKA, D.-MATCZAK, A. (2002): Urbanization in Poland: Tendencies and transformation European Urban and Regional Studies 9 (1): 39-46. https://doi.org/10.1177/096977640200900104

TIMÁR, J.-VÁRADI, M. M. (2001): The uneven development of suburbanization during transition in Hungary European Urban and Regional Studies 8 (4): 349-360. https://doi.org/10.1177/096977640100800407

TóTH, J. (2008): Meditáció a városokról és a várossá nyilvánítás hazai gyakorlatáról. Vitairat Területi Statisztike (48) 3: 237-244.

Tsenkova, S. (2006): Beyond transitions: Understanding urban change in post-socialist cities In: Tsenkova, S.-Nedović-Budić, Z. (eds.) The Urban Mosaic of Postsocialist Europe pp. 21-50., Springer Verlag, Berlin.

VERESS, N. Cs. (2016): Romania's youngest towns - How urban are they? Studia Universitatis Babes-Bolyai, Geographia (61) 1: 67-88.

ZANIEWSKA, H. (2013): Rozwój miejskiej sieci osadniczej pod wpływem nadawania statusu miasta nowym jednostkom In: GACZEK, W. M. (red.) Dynamika, cele i polityka zintegrowanego rozwoju regionów: aspekty teoretyczne $i$ zarzadzanie w przestrzeni pp. 191-201., Bogucki Wydawnictwo Naukowe, Poznań.

Regional Statistics, Vol. 8. No. 2. 2018: 135-153; DOI: 10.15196/RS080202 